\title{
Phylogeny and Antibiotic Susceptibility of Bacteria in Sediments of Aegean Sea
}

\author{
Ilknur Tuncer \\ Institute of Marine Sciences and Technology, Dokuz Eylul University, Turkey
}

Copyright $\bigcirc 2017$ by authors, all rights reserved. Authors agree that this article remains permanently open access under the terms of the Creative Commons Attribution License 4.0 International License

\begin{abstract}
The bacterial diversity and antimicrobial resistance in coastal areas indicate the variability in the community structures and metabolic activities. In the present study, antibiotic susceptibility and phylogenetic analysis of bacteria isolated from stations with different depths and influenced by terrestrial and marine fluxes in eastern Aegean Sea were illustrated. Half of the isolates were found as resistant and 14 percent showed high MAR index indicating the high-risk sources of contamination in the environment. According to $16 \mathrm{~S}$ rRNA gene analysis, the isolates were found as belonging to the phylum Firmicutes and the class Gammaproteobacteria with the genera Bacillus, Halomonas, Oceanobacillus, Photobacterium, Pseudoalteromonas, Psychrobacter and Vibrio. Approximately half of Bacillus strains which were dominant among all isolates were resistant. In addition to phylogenetically diverse bacteria, the variability in resistance, intermediate and high MAR index levels of the study area indicated the effect of geographical differences.
\end{abstract}

Keywords Bacterial Diversity, Multiple Antibiotic Resistance, 16S rRNA Genes, Sediment, Aegean Sea

\section{Introduction}

Bacteria in marine environments show different diversity and resistance patterns. Limited number of studies in the coastal areas influenced by terrestrial and marine fluxes indicated the high bacterial diversity [1-5], and multiple resistance [5-11].

Studies in coastal sediments, especially beneath fish farms, near shore sediments and sandy beaches which are under high anthropogenic pressure, also demonstrated bacterial community changes and high levels of antibiotics in the sediments [6-9]. Unlike widespread antibiotic resistance in those areas, the susceptibility levels are expected to increase in the deep-basins. For instance, a recent study in coastal areas of Eastern Mediterranean Sea including Turkish coasts of Aegean Sea demonstrated the high multiple antibiotic resistance but no resistance in offshore North Aegean Sea [12].

In the present study, the phylogenetic analysis and antibiotic resistance of bacteria isolated from sediments of Aegean Sea were aimed.

\section{Materials and Methods}

\subsection{Sampling}

In the survey by RV/K Piri Reis research vessel in spring period, sediment samples were obtained from 5 stations (100-202 m depths) located between Lesvos Island and Karaburun in Aegean Sea (Figure 1).

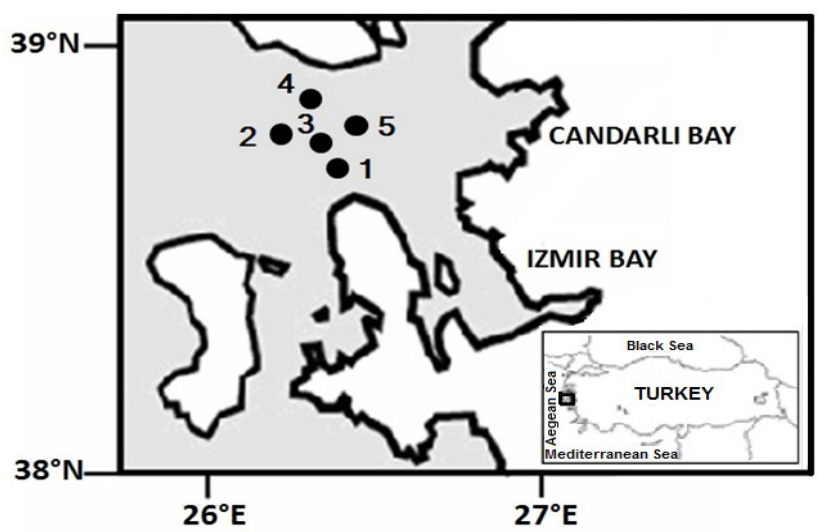

Figure 1. Stations between Lesvos Island and Karaburun in Aegean Sea

\subsection{Isolation of Bacteria}

Bacteria were isolated using three different sediment processing methods and six isolation media prepared with sterile seawater. The isolation media consisted of the following: M1, $18 \mathrm{~g}$ agar, $10 \mathrm{~g}$ starch, $4 \mathrm{~g}$ yeast extract, $2 \mathrm{~g}$ peptone, 1 liter sterile seawater; M2, $18 \mathrm{~g}$ agar, $1 \mathrm{~g}$ starch, $0.4 \mathrm{~g}$ yeast extract, $0.2 \mathrm{~g}$ peptone, 1 liter sterile seawater; $\mathrm{M} 3$, 
$18 \mathrm{~g}$ agar, $2.5 \mathrm{~g}$ starch, $1 \mathrm{~g}$ yeast extract, $0.5 \mathrm{~g}$ peptone, $750 \mathrm{ml}$ sterile seawater, $250 \mathrm{ml}$ distilled water; M4, $18 \mathrm{~g}$ agar, 1 liter sterile seawater; M5, $18 \mathrm{~g}$ agar, $750 \mathrm{ml}$ sterile seawater, $250 \mathrm{ml}$ distilled water; M6 (Difco ${ }^{\mathrm{TM}}$ marine agar), $55 \mathrm{gr}$ medium, 1 liter distilled water.

For the first sediment processing method, $10 \mathrm{ml}$ wet sediment sample was dried overnight and 0.5 gr dry sediment was aseptically spread in circular fashion onto the agar media. For the next method, $1 \mathrm{ml}$ wet sediment was diluted with sterile seawater (1:4) and $50 \mu 1$ was spread aseptically onto the agar media. And lastly, $0.5 \mathrm{~g}$ dry sediment was mixed with $4 \mathrm{ml}$ sterile seawater and $50 \mu \mathrm{l}$ was spread aseptically onto the agar media. Incubation was done at $26^{\circ} \mathrm{C}$ for $2-3$ days. Then, isolates were cryopreserved with $50 \%$ glycerol at $-20^{\circ} \mathrm{C}$.

\subsection{Antibiotic Resistance}

Eleven antimicrobial agents from different classes of antibiotics were chosen as amikacin $30 \mu \mathrm{g}(\mathrm{AN})$, ampicillin

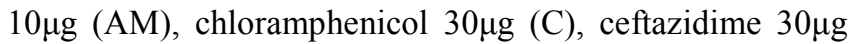

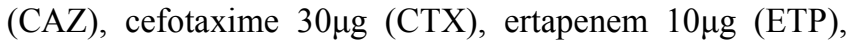
gentamicin $10 \mu \mathrm{g}(\mathrm{GM})$, kanamycin $30 \mu \mathrm{g}(\mathrm{K})$, nalidixic acid $30 \mu \mathrm{g}$ (NA), trimethoprim/sulfamethoxazole $1.25 \mu \mathrm{g} / 23.75 \mu \mathrm{g}$ (SXT), tetracycline $30 \mu \mathrm{g}$ (TE). Antibiotic tests were performed with disc diffusion method according to Performance Standards for Antimicrobial Disk Susceptibility Tests issued by Clinical and Laboratory Standards Institute [13].

\subsection{Phylogenetic Analysis}

Genomic DNA of isolated bacteria was extracted with a commercial kit (Invitrogen, Carlsbad, CA) according to the user's manual for both Gram-negative and Gram-positive bacterial cell lysate. Then, 16S rRNA genes were amplified from genomic DNA by PCR using the universal primer pairs of FC27 (5'-AGAGTTTGATCCTGGCTCAG-3') and RC1492 (5'-TACGGCTACCTTGTTACGACTT-3') and also the pairs of $63 \mathrm{f}$ (5'-CAGGCCTAACACATGCAAGTC-3') and $1387 \mathrm{r}$ (5'-GGGCGGWGTGTACAAGGC-3'). The $50 \mu 1$ PCR mixture contained 20 to 50 ng of DNA, One Taq Quik-Load 2X Master mix (New England Biolabs, Inc. Beverly, MA), 10 pmol of each primer (Fermentas, Thermo Fisher Scientific, Waltham, MA), and $10 \mathrm{mM}$ deoxynucleoside triphosphate mixture (Fermentas, Thermo Fisher Scientific, Waltham, MA). The PCR program consisted of 30 cycles of $94^{\circ} \mathrm{C}$ for $1 \mathrm{~min}, 55^{\circ} \mathrm{C}$ for $1 \mathrm{~min}$, and $72^{\circ} \mathrm{C}$ for $1 \mathrm{~min}$ followed by a final extension step at $72^{\circ} \mathrm{C}$ for $7 \mathrm{~min}$. Amplification products were examined by agarose gel electrophoresis.

Sequencing service was taken from Izmir Institute of Technology (IZTECH, Turkey) and Gene Research and Technology (RefGen, Turkey). For the phylogeny, all nucleotide sequences were analyzed using Geneious (version
6.1; Biomatters Ltd., NZ) and compared within the NCBI database (http://www.ncbi.nlm.nih.gov/) using the Basic Local Alignment Search Tool (BLAST). Phylogenetic analysis was performed using Mega with 1000 bootstrap neighbor-joining method [14]. All those 16S rRNA gene sequences have been deposited into GenBank database (http://www.ncbi.nlm.nih.gov/GenBank/index.html) under the accession numbers KC815716 - KC815731, KC815744 - KC815755, KC815825 - KC815847.

\section{Results and Discussion}

\subsection{Antibiotic Susceptibility}

According to antibiotic tests of totally 51 isolates, approximately half of them were found as resistant (51\%) and $41 \%$ were intermediate to at least one of eleven antibiotics. On the other hand, the resistance and the intermediate levels of the study area were $38-60 \%$ and $11-$ $38 \%$, respectively (Table 1). When multiple antibiotic resistance (MAR) index was calculated, $14 \%$ of all strains showed high MAR index indicating the high-risk sources of contamination in the environment. Furthermore, $10-40 \%$ of isolates from only stations $3-5$ had this high index (Table $1)$.

Table 1. Antibiotic susceptibility percentages of the stations in Aegean Sea.

\begin{tabular}{|c|c|c|c|c|}
\hline Stations & R (\%) & I (\%) & S (\%) & High MAR (\%) \\
\hline 1 & 38 & 38 & 23 & 0 \\
\hline 2 & 44 & 22 & 33 & 0 \\
\hline 3 & 56 & 11 & 33 & 22 \\
\hline 4 & 50 & 20 & 30 & 10 \\
\hline 5 & 60 & 30 & 10 & 40 \\
\hline
\end{tabular}

R: resistance, I: intermediate, S: susceptiblity, MAR: multiple antibiotic resistance

The highest resistance was measured for AN (49\%) and then for CAZ (19\%). Similarly, the highest intermediate level was obtained for AN (38\%) but then for K, NA and CTX (17\%, $17 \%, 14 \%$, respectively). Multiple resistance and also multiple intermediate levels were highly seen at the stations 3-5 (Figure 2). However, there was no resistance to C, ETP, NA, SXT, TE and no intermediate strain for AM, C, ETP, GM.

The present study demonstrated the variability of antibiotic resistance in sediments of different stations and indicated multiple resistance in stations closer to coastal area like high multiple resistance seen in coastal environments [5-11]. In spite of scarcity in bacterial research at Turkish marine environment, high MAR index was also previously shown in Turkish coastal seawaters and sediments $[12,15-17]$. 


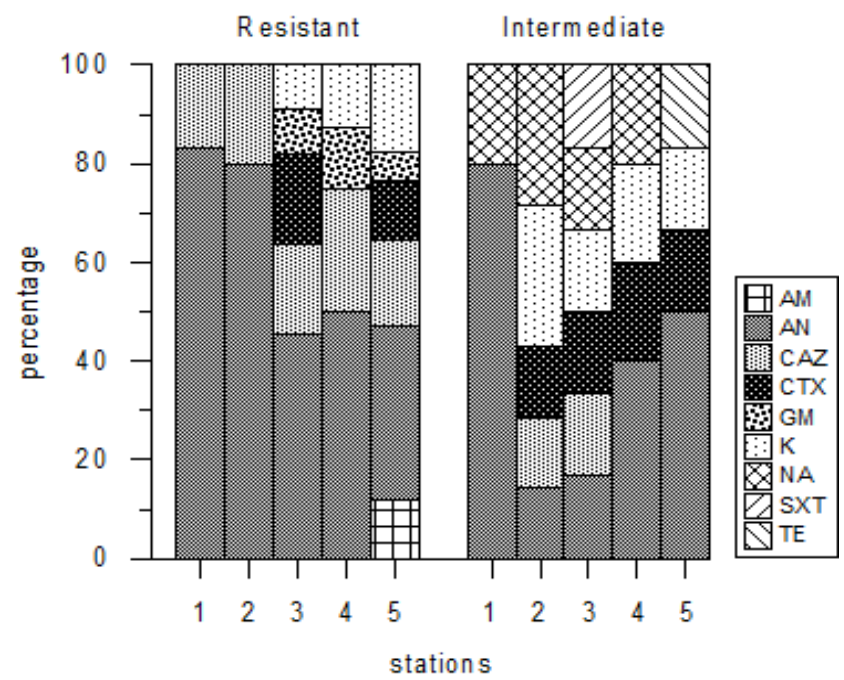

Figure 2. For eleven antibiotics, the percentages of resistant and intermediate levels for strains isolated from Aegean Sea sediments. Amikacin $30 \mu \mathrm{g}(\mathrm{AN})$, ampicillin $10 \mu \mathrm{g}(\mathrm{AM})$, chloramphenicol $30 \mu \mathrm{g}(\mathrm{C})$, ceftazidime $30 \mu \mathrm{g}(\mathrm{CAZ})$, cefotaxime $30 \mu \mathrm{g}$ (CTX), ertapenem $10 \mu \mathrm{g}$ (ETP), gentamicin $10 \mu \mathrm{g}(\mathrm{GM})$, kanamycin $30 \mu \mathrm{g}(\mathrm{K})$, nalidixic acid $30 \mu \mathrm{g}(\mathrm{NA})$, trimethoprim/sulfamethoxazole $1.25 \mu \mathrm{g} / 23.75 \mu \mathrm{g}$ (SXT), tetracycline $30 \mu \mathrm{g}$ (TE).

In a previous study of Eastern Mediterranean Sea, the relation between antibiotic resistance and geographical differences was given as higher resistance in coastal areas of Syria than Turkey and Lebanon $(48 \%, 38 \%$ and $31 \%$ of total isolates, respectively) [12]. Moreover, limited number of studies in Turkish coastal environment have reported resistant bacteria for the coasts of Marmara Sea [15], Aegean Sea and North Levantin Sea [12]. Similarly, very high resistance and MAR index were obtained for isolates from coastal sediments of Izmir Bay in Aegean Sea influenced by river and sewage discharge, anthropogenic activities such as tourism-derived, industrial, agricultural and nautical activities [17]. On the other hand, in the present study, one of the lowest resistance without high MAR index was obtained in station 2 with $200 \mathrm{~m}$ depth and closer to open Aegean Sea which supported the previous findings as the decrease in resistance from coastal to offshore area in North Aegean Sea [12]. Moreover, compared to the present study in Aegean Sea, higher resistance and MAR index were obtained from coastal sediments of Izmir Bay [17] and there were lower resistance and MAR index in deep stations of Eastern Mediterranean Sea with different bacterial diversity levels [18].

\subsection{Phylogeny and Resistance}

According to $16 \mathrm{~S}$ rRNA gene analysis, it was found that the isolates belonged to the phylum Firmicutes and the class Gammaproteobacteria. The phylogenetic tree constructed using nearly full $16 \mathrm{~S}$ rRNA gene sequence of one representative isolate for each nearest type strain clearly supported those phyla forming two separate clades (Figure 3).

The Bacillus species were dominant among all isolates and the other genera obtained from the study area were Oceanobacillus, Halomonas, Photobacterium, Pseudoalteromonas, Psychrobacter and Vibrio. Approximately half of all Bacillus strains were resistant (47\%) and intermediate (42\%). While high MAR index was obtained from Oceanobacillus and Photobacterium species, Psychrobacter and Vibrio species were sensitive to all antibiotics (Figure 4). In addition, Psychrobacter Photobacterium and Vibrio species isolated from the study area had no intermediate levels for all antibiotics (Figure 4).

$80 \%$ of the resistant isolates in stations $1,3,4$ and $67 \%$ in station 5 were Bacillus strains (Figure 4). Similarly, approximately $80 \%$ of the intermediate levels in stations 1,4 , 5 , all resistance in station 2 and all intermediate levels in stations 2, 3 came from Bacillus species (Figure 4).

\section{Resistant and Intermediate genera}

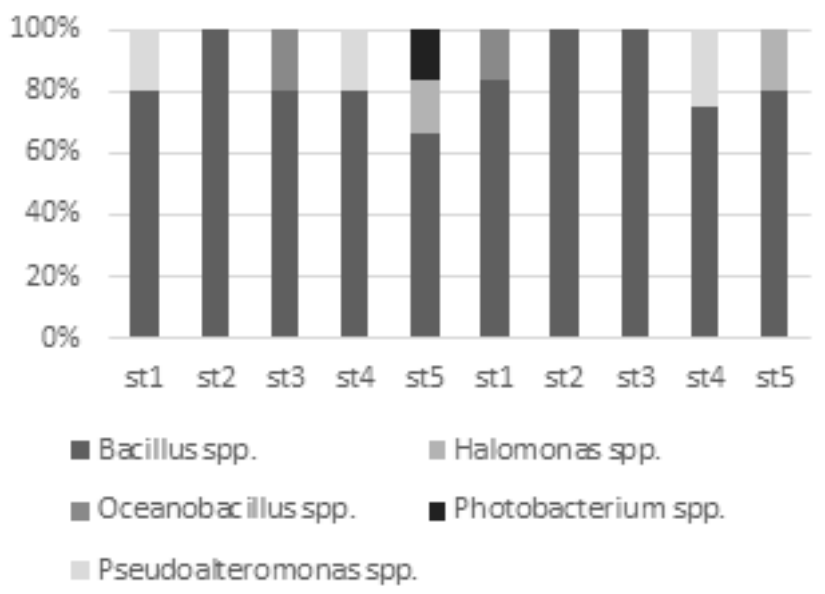

Figure 4. The percentages of resistant and intermediate genera, respectively isolated from 5 stations in Aegean Sea.

Highly resistant and diverse Bacillus species belonging to the phylum Firmicutes were dominant among isolates in the study area. Similarly, resistant Bacillus species were dominantly seen beneath fish farms in Gulf of La Spezia, North Mediterranean Sea [6] and Gulf of Mannar, India [5]. Although lower bacterial diversity in higher taxa was obtained compared to phylogenetic composition of resistant isolates from near shore sediments in Gulf of Mannar, India [5], higher diversity in lower taxa was clearly seen in the present study.

Furthermore, the study area was in the middle of north Aegean Sea and west Levantin Sea in Eastern Mediterranean Sea and as supporting this geographical indication, the study area had the highest bacterial diversity in both lower and higher taxa compared to coastal sediments of Izmir Bay having terrestrial and anthropogenic effects and thus the highest resistance and bacterial diversity in higher taxa [17] and to deep and oligotrophic stations in Aegean Sea having higher antibiotic sensivity and phylogenetic diversity in lower taxa [18]. 


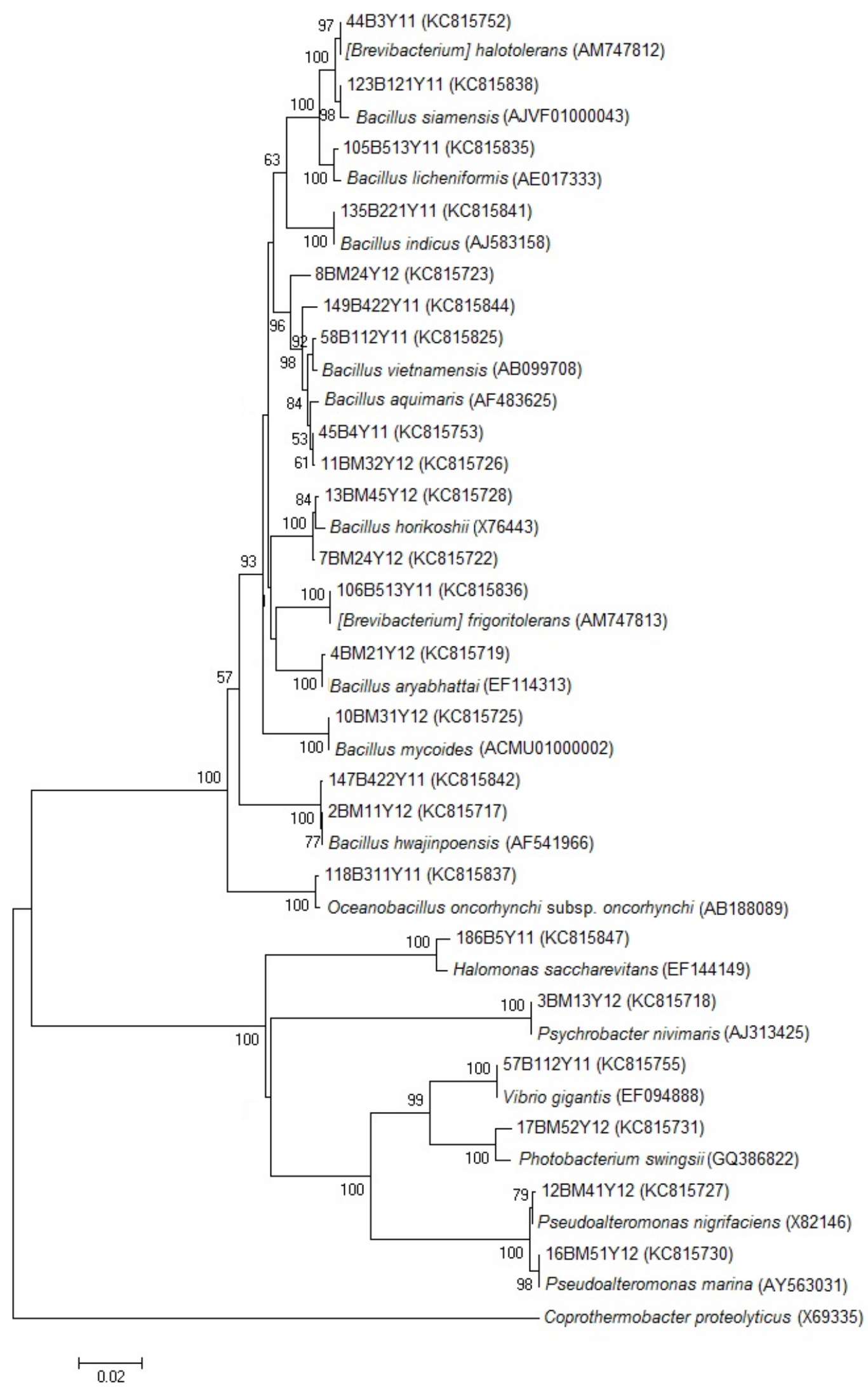

Figure 3. Neighbor-joining distance tree constructed in Mega using partial 16S rRNA gene sequences. GenBank accession numbers were given in parentheses. Bootstrap values calculated from 1000 re-samplings were in percentage. Coprothermobacter proteolyticus was used to position the root. 


\section{Conclusions}

In addition to phylogenetically diverse bacteria, the variability in resistance, intermediate and high MAR index levels of the study area indicated the effect of geographical differences. Therefore, much more studies in bacterial diversity and antimicrobial resistance in coastal areas are needed to understand the variability in the community structures in association with environmental differences.

\section{Acknowledgements}

The author would like to thank to crew of RV/K Piri Reis research vessel and Scientific Research Project Coordination Unit, Dokuz Eylul University, Turkey for funding this work as project no. 2010.KB.FEN.014.

\section{REFERENCES}

[1] M. M. Aguilo-Ferretjans, R. Bosch, C. Martin-Cardona, J. Lalucat, B. Nogales. Phylogenetic analysis of the composition of bacterial communities in human-exploited coastal environments from Mallorca Island (Spain), Systematic and Applied Microbiology, Vol. 31, 231-240, 2008.

[2] K. M. Kelly, A. Y. Chistoserdov. Phylogenetic analysis of the succession of bacterial communities in the Great South Bay (Long Island), FEMS Microbiology Ecology, Vol.35, 85-95, 2001

[3] A. J. F. C. Oliveira, H. C. Hollnagel, H. S. L. Mesquita, R. F. C. Fontes. Physical, chemical and microbiological characterization of the intertidal sediments of Pereque Beach, Guaruja (SP), Brazil, Marine Pollution Bulletin, Vol.54, 921927, 2007.

[4] A. Pianetti, F. Bruscolini, L. Sabatini, P. Colantoni. Microbial characteristics of marine sediments in bathing area along Pesaro-Gabicce coast (Italy): A preliminary study, Journal of Applied Microbiology, Vol. 97, 682-689, 2004.

[5] R. Saravanakumar, J. Ronald, K. Maheswari, U. Ramesh. Phylogenetic identification of antimicrobial active marine bacteria from sediments of the coasts of Southeast India, International Journal of Applied Bioscience, Vol.1, 5-14, 2011

[6] E. Chelossi, L. Vezzulli, A. Milano, B. M. Branzoni, M. Fabiano, G. Riccardi, I.M. Banat. Antibiotic resistance of benthic bacteria in fish farm and control sediments of the Western Mediterranean, Aquaculture, Vol. 219, 83-97, 2003.

[7] Z. J. Mudryk. Occurrence and distribution antibiotic resistance of heterotrophic bacteria isolated from a marine beach, Marine
Pollution Bulletin, Vol. 50, 80-86, 2005.

[8] A. J. F. C. Oliveira, J. M. W. Pinhata. Antimicrobial resistance and species composition of Enterococcus spp. isolated from waters and sands of marine recreational beaches in Southeastern Brazil, Water Research, Vol. 42, 2242-2250, 2008 .

[9] A. J. F. C. Oliveira, P. T. R. Franca, A. B. Pinto Antimicrobial resistance of heterotrophic bacteria isolated from seawater and sands of recreational beaches with different organic pollution levels in southeastern Brazil: evidences of resistance dissemination, Environmental Monitoring and Assessment, Vol. 169, 335-384, 2010.

[10] P. Perlinski, Z. Mudryk. Inhibitory effect of antibiotics on the growth of heterotrophic bacteria inhabiting marine beach, Baltic Coastal Zone, Vol.13, No.2, 15-24, 2009.

[11] P. Ruban, C. Gunaseelan. Antibiotic resistance of bacteria from Krishna Godovari Basin, Bay of Bengal, India, Environmental and Experimental Biology, Vol. 9, 133-136, 2011.

[12] G. Altug, M. Cardak, P. S. Ciftci, S. Gurun, A. A. Saad, A. Ibrahim, M. Fakhri. Distribution and antibiotic resistance of heterotrophic and indicator bacteria in the coastal areas of Turkey, Syria and Lebanon, Rapport Commission International Mer Mediterranee, Vol.39, 333, 2010.

[13] Clinical Laboratory Standards Institute (CLSI), Performance standards for antimicrobial disk susceptibility tests; approved standard $-11^{\text {th }}$ ed. Wayne, Pennsylvania, USA, 2012.

[14] K. Tamura, D. Peterson, N. Peterson, G. Stecher, M. Nei, S. Kumar,. MEGA5: Molecular Evolutionary Genetics Analysis using Maximum Likelihood, Evolutionary Distance, and Maximum Parsimony Methods, Molecular Biology and Evolution, Vol.28, 2731-2739, 2011.

[15] T. Akkan, A. Kaya, S. Dincer. Antibiotic levels and heavy metal resistance in Gram-negative bacteria isolated from seawater, Iskenderun Organized Industrial Zone, Journal of Applied Biological Science, Vol.7, No.1, 10-14, 2013.

[16] N. Sivri, G. Ozbayram, Z. Karatut. Antibiotic resistance of enteric bacteria isolated from south-western Istanbul coast (Turkey), Rapport Commission International Mer Mediterranee, Vol. 39, 402, 2010.

[17] I. Tuncer, N. Bizsel. Phylogenetic diversity and antimicrobial activities of bacteria isolated form coastal sediments of Izmir Bay, Aegean Sea, International Journal of Advances in Science Engineering and Technology, Vol. 5, No. 2, 29-34, 2017.

[18] I. Tuncer, N. Bizsel. Antibiotic resistance and phylogeny of bacterial isolates with biogeochemical analysis from sediments of Eastern Mediterranean Sea in association with environmental parameters. Journal of Clinical \& Experimental Immunology, Vol. 1, No. 2, 15-20, 2016. 